\title{
ADAPTASI PADI SAWAH (Oryza sativa L.) TERHADAP PENINGKATAN KELEBIHAN AIR SEBAGAI DAMPAK PEMANASAN GLOBAL
}

\author{
Putu Santhiawan ${ }^{1}$ dan Putu Suwardike ${ }^{1}$ \\ E-mail : putushantiawan@gmail.com \\ ${ }^{1}$ Program Studi Agroteknologi, Fakultas Pertanian, Universitas Panji Sakti \\ Jl. Bisma, No 22 Singaraja, Bali, Indonesia 81116
}

\begin{abstract}
Climate change as a result of global warming creates climate uncertainty (anomaly) in the form of excessive drought (El-Nino) and excessive rain (La Nina) which greatly affects the productivity of rice plants. Under normal conditions. Indonesia's rice production will decline to 65 million tons in 2050. But due to climate change, the decline in rice production can be even more drastic to reach 90 million tons or down by 38 per cent. Rice plants need around 2,500 litres of water to produce $1 \mathrm{~kg}$ of grain (rough rice). This water is filled from rainwater and/or irrigation water. La Nina can interfere with the growth and yield of rice plants because the plants suffer damage due to limited air exchange, both in the form of carbon dioxide (CO2) and oxygen (O2) which inhibits the process of photosynthesis and plant respiration. The level of growth disturbance and yield of rice due to excess water depends on the tolerance level of the variety, the level of inundation and the length of time of inundation. Physiologically the adaptation of lowland rice plants to excess water is classified as complex. Plants that produce PDC and ADH are more tolerant of inundation. Molecularly, plants that contain the Sub1 gene are more resistant to excess water.
\end{abstract}

Keywords: flooding, global warming, climate change, rice, food

\begin{abstract}
Abstrak. Perubahan iklim (climate change) sebagai dampak pemanasan global menimbulkan ketidakpastian (anomali) iklim berupa kekeringan yang berlebihan (El-Nino) dan hujan yang berlebihan (La Nina) yang sangat berpengaruh terhadap produktivitas tanaman padi. Dalam kondisi normal. produksi padi di Indonesia akan mengalami penurunan hingga 65 juta ton pada tahun 2050. Namun akibat perubahan iklim, penurunan produksi padi dapat lebih derastis hingga mencapai 90 juta ton atau turun hingga 38 persen. Tanaman padi membutuhkan sekitar 2.500 liter air untuk menghasilkan $1 \mathrm{~kg}$ butir gabah (rough rice). Air ini dipenuhi dari air hujan dan/atau air irigasi. La Nina dapat mengganggu pertumbuhan dan hasil tanaman padi karena tanaman mengalami kerusakanakibat terbatasnya pertukaran udara, baik berupa karbondioksida $\left(\mathrm{CO}_{2}\right)$ maupun oksigen $\left(\mathrm{O}_{2}\right)$ yang menghambat proses fotosintesis dan respirasi tanaman. Tingkat gangguan pertumbuhan dan hasil tanaman padi akibat kelebihan air tergantung pada tingkat toleransi varietas, tingkat genangan dan lama waktu terjadinya genangan. Secara fisiologis adaptasi tanaman padi sawah terhadap kelebihan air tergolong kompleks. Tanaman yang menghasilkan PDC dan ADH lebih banyak lebih toleran terhadap genangan. Secara molekuler, tanaman yang mengandung gen Sub1 lebih tahan terhadap kelebihan air.
\end{abstract}

Katakunci: penggenangan, pemanasan global, perubahan iklim, padi, pangan

\section{PENDAHULUAN}

Tantangan sektor pertanian khususnya dalam penyediaan pangan bagi penduduk cenderung semakin berat karena di satu sisi, jumlah penduduk meningkat dibarengi dengan perubahan preferensi (selera) dan kesadaran akan kesehatan menuntut kuantitas dan kualitas bangan yang semakin meningkat. Namun di sisi lain, ketersediaan lahan pertanian subur semakin berkurang kerena alih fungsi untuk kegiatan non pertanian, ditambah kondisi iklim yang tidak menentu (anomali) sebagai dampak pemanasan global (global warming).

Produksi beras nasional pada kurun waktu 5 (lima) tahun terakhir (2011-2015) tampak cenderung meningkat. Produksi beras tahun 2011 sekitar 65,4 juta ton, naik 
menjadi 69,1 juta ton tahun 2012, terus mengalami peningkatan hingga mencapai sekitar 75 ton tahun 2015 (http://www.indonesia-

investments.com/id/bisnis/komoditas (beras). BPS RI melaporkan bahwa konsumsi beras per kapita per tahun mengalami penurunan dari $124 \mathrm{~kg}$ menjadi $114 \mathrm{~kg}$. Namun jika dibandingkan dengan pertumbuhan penduduk dan perkembangan selera akan pangan tampak bahwa ketersediaan beras ke depan masih mengkhawatirkan. Dalam kondisi tidak terjadi perubahan iklim, produksi padi di Indonesia akan mengalami penurunan hingga 65 juta ton pada tahun 2050. Akibat perubahan iklim, penurunan produksi padi dapat lebih derastis hingga mencapai 90 juta ton atau turun hingga 38 persen.

Sebagaimana telah disinggung pada alenia di atas, salah satu kendala sektor pertanian dalam memenuhi ketersediaan pangan yang cukup bagi penduduk adalah adanya peningkatan suhu rata-rata atmosfer, laut dan daratan yang dikenal dengan pemanasan global. Salah satu dampak pemanasan global yang sangat dirasakan bagi sektor pertanian adalah perubahan iklim (climate change) yang menjurus pada ketidakpastian (anomali) iklim berupa kekeringan yang berlebihan (El-Nino) dan hujan yang berlebihan (La Nina).

Pada kejadian La Nina, suhu permukaan laut di kawasan barat pasifik menghangat dan menimbulkan curah hujan yang tinggi di kawasan Asia Tenggara dan Australia. Wujud dari fenomena La Nina adalah kenaikan curah hujan di atas normal dan kenaikan kelembaban udara. Kondisi ini dapat berdampak buruk terhadap produksi pangan, khususnya padi karena sering menimbulkan banjir (kelebihan air) dan meningkatnya gangguan organisme pengganggu tanaman (Hattori, 2011; Suciantini, 2015).

Padi membutuhkan air yang cukup untuk pertumbuhan dan perkembangannya. Kebutuhan air dimaksud merupakan jumlah air yang dibutuhkan oleh tanaman untuk melakukan proses pertumbuhannya mulai dari tanam hingga panen yang dapat diketahui melalui kehilangan air akibat evapotranspirasi. Meskipun padi, khususnya padi sawah lazim ditanam dengan metode penggenangan, tetapi padi bukanlah merupakan tanaman air (hidrofit). Padi mampu hidup dalam kondisi tergenang karena memiliki kemampuan mengoksidasi lingkungan perakarannya sendiri. Kemampuan mengoksidasi ini berbeda-beda tergantung daya adaptasi masing-masing jenis atau varietas padi. Secara prinsip padi sawah lebih toleran genangan dibanding padi gogo, dan padi sawah rawa lebak atau sawah pasang surut lebih toleran terhadap genangan dibanding padi sawah biasa. Kemampuan adaptasi varietasvarietas padi sawah terhadap kelebihan air juga bervariasi, tergantung sifat genetik varietas bersangkutan. Secara umum, padi sawah dapat bertahan dalam kondisi kelebihan air karena memiliki kemampuan adaptasi yang tinggi terhadap kelebihan air. Terdapat beragam pendapat tentang kemampuan adaptasi padi sawah terhadap kelebihan air, seperti perbedaan kemampuan morfologis (Suwignyo, 2007), kemampuan fisiologis (Suwignyo, 2007; Ta Liao dan Ho Lin, 2001; Hairmansis et al., 
2012; Mahmod et al, 2014), karena pengaruh level ABA dan IAA endogenous (Mapelli et al., 1995), akibat kinerja ethylene (Dai et al., 2012), dan berbagai mekanisme adaptasi lainnya. Toleransi tanaman padi sawah terhadap kelebihan air dapat diamati dari perbedaan mekanisme fisiologis ataupun molekuler.

Pada makalah ini lebih lanjut diulas secara ringkas fenomena pemanasan global, khususnya La Nina, dampaknya terhadap pertanaman padi sawah dan adaptasi tanaman padi sawah terhadap peningkatan kelebihan air.

\section{PEMBAHASAN}

\section{Fenomena Pemanasan Global}

Perhatian serius para ahli terhadap fenomena pemanasan global dimulai ketika pada tahun 1988, Badan PBB untuk lingkungan (United Nations Enviroment Programme) dan organisasi meteorologi dunia (World Meteorology Organization) mendirikan sebuah panel antar pemerintah untuk perubahan iklim (Intergovernmental Panel on Climate Change/IPCC) yang terdiri atas 300 lebih pakar perubahan iklim dari seluruh dunia. Pada pertemuan tahun 1990 dan 1992, IPCC menyimpulkan bahwa penggandaan jumlah Gas Rumah Kaca (GRK) di atmosfer mengarah pada konsekuensi serius bagi masalah sosial, ekonomi, dan sistem alam di dunia. Selain itu, IPCC menyimpulkan bahwa emisi GRK yang dihasilkan dari aktivitas manusia juga memberikan kontribusi pada GRK alami dan menyebabkan atmosfer bertambah panas.

Secara konsep, pemanasan global atau global warming diartikan sebagai kondisi meningkatnya suhu rata-rata atmosfer, bumi, dan lautan. Pemanasan global menyebabkan terjadinya perubahan iklim (climate change) yang dapat diketahui dari perubahan signifikan unsur-unsur iklim, terutama suhu udara dan curah hujan selama kurun waktu 30 tahun atau lebih. Dampak ekstrem dari perubahan iklim terutama adalah terjadinya kenaikan temperatur serta pergeseran musim.

Dalam satu abad terakhir suhu permukaan bumi telah meningkat antara $0,74-0,18^{\circ} \mathrm{C}$. Di Indonesia, menurut data Badan Perencanaan Pembangunan Nasional (Bappenas), suhu rata-rata udara di permukaan tanah mengalami peningkatan sebesar $0,5^{\circ} \mathrm{C}$.

\section{Konsepsi Peningkatan Kelebihan}

Air

\begin{tabular}{llr}
\multicolumn{2}{c}{ Sebagaimana } & telah \\
disinggung & pada & bagian \\
pendahuluan, & tanaman & padi
\end{tabular} membutuhkan air yang cukup agar dapat tumbuh dan berkembang secara normal. Kebutuhan air tanaman didefinisikan sebagai jumlah air yang dibutuhkan oleh tanaman pada suatu periode untuk dapat tumbuh dan produksi secara normal. Kebutuhan air nyata untuk areal usaha pertanian meliputi evapotranspirasi (ET), sejumlah air yang dibutuhkan untuk pengoperasian secara khusus seperti penyiapan lahan dan penggantian air, serta kehilangan selama pemakaian. Sehingga kebutuhan air dapat dirumuskan sebagai berikut:

$$
\mathrm{KAI}=\mathrm{ET}+\mathrm{KA}+\mathrm{KK}
$$

Dimana:

KAI $=$ Kebutuhan Air Irigasi (mm)

$\mathrm{ET}=$ Evapotranpirasi $(\mathrm{mm} / \mathrm{hari})$

$\mathrm{KA}=$ Kehilangan Air (mm)

$\mathrm{KK}=$ Kebutuhan Khusus (mm) 
Tanaman dikatakan kelebihan air jika ketersediaan air melebih kebutuhannya atau menganggu proses-proses fisiologi tanaman bersangkutan. Kelebihan air tanah telah lama diidentifikasi sebagai salah satu cekaman abiotik utama dan kendala yang diberikannya pada akar memiliki pengaruh yang signifikan terhadap pertumbuhan dan perkembangan tanaman.

Tanaman padi membutuhkan sekitar 2.500 liter air untuk menghasilkan $1 \mathrm{~kg}$ butir gabah (rough rice) (Mahmod et al., 2014). Air ini dipenuhi dari air hujan dan/atau air irigasi untuk memenuhi kebutuhan air guna mengganti kehilangan air akibat evapotranspirasi, peresapan (seepage) dan perkolasi (Bouman, 2009).

Pada kelompok tanaman non hidrofit, air yang berlebihan yang terdapat dalam tanah pada kelompok tanaman non hidrofit tidak dapat dipakai oleh tanaman karena akar tidak mampu menyerap air secara aktif. Tanpa $\mathrm{O}_{2}$ (hipoksia), sel-sel akar tidak dapat bertahan hidup lama, hingga akhirnya mati. Sel-sel akar yang rusak atau mati terutama sel-sel xylemnya tidak dapat melakukan penyerapan air secara aktif sehingga air tidak terserap dan terangkut ke bagian atas tanaman. Kondisi terbatasnya $\mathrm{O}_{2}$ secara dramatis akan mempengaruhi pertumbuhan, perkembangan, dan keberadaan tanaman.

\section{Pertumbuhan dan Perkembangan Tanaman Padi Sawah}

Secara garis besar, fase pertumbuhan tanaman padi dibagi menjadi 2 (dua) stadia yaitu stadia vegetatif dan stadia generatif. Beberapa ahli membedakan lebih lanjut stadia generatif menjadi 2 (dua) fase, yaitu fase reproduktif dan pematangan. Lama masing-masing stadia tergantung verietas dan kondisi lingkungan tumbuh tanaman padi. Untuk tanaman padi genjah yang berumur sekitar 120 hari, lama waktu masing-masing stadia seperti tersaji pada gambar berikut.

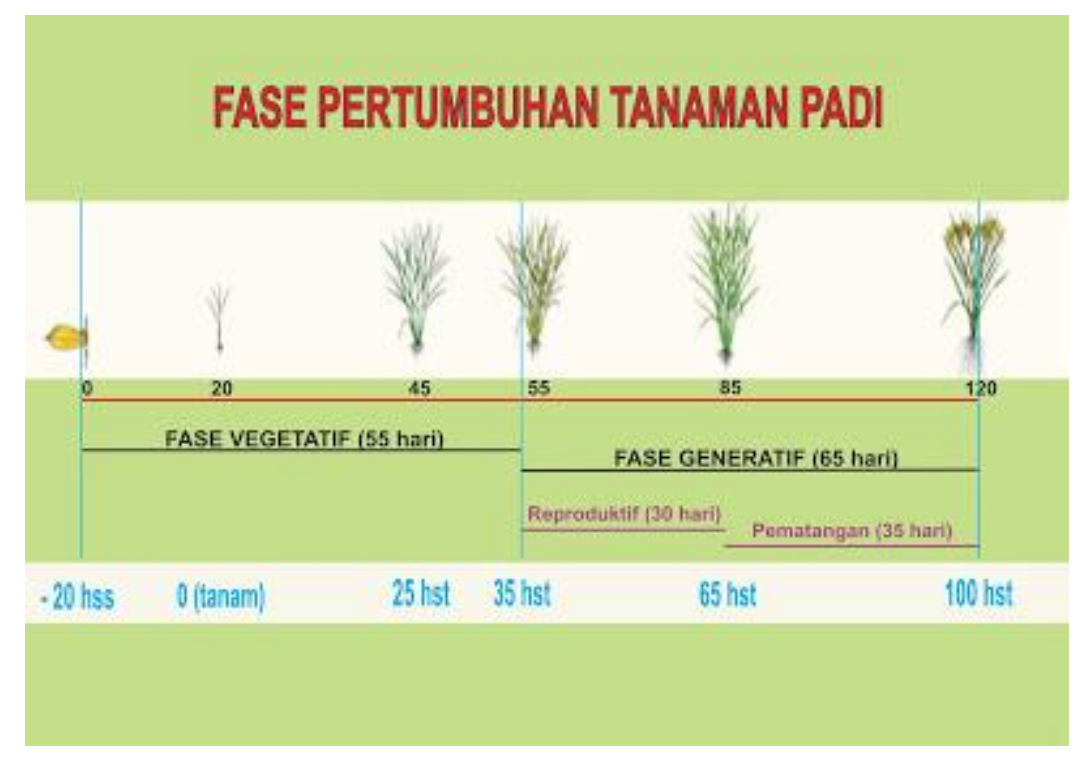

Gambar 1. Fase pertumbuhan tanaman padi 
Stadia vegetatif adalah awal pertumbuhan tanaman padi, mulai dari perkecambahan benih sampai primordia bunga (pembentukan malai). Fase reproduktif yang diawali dari inisiasi bunga sampai pembungaan (setelah putik dibuahi oleh serbuk sari) berlangsung sekitar 35 hari. Perbedaan lama periode fase reproduktif antara padi varietas genjah maupun yang berumur panjang tidak berbeda nyata. Periode pematangan, dari tahap masak susu hingga gabah matang penuh atau masak fisiologis berlangsung selama sekitar 35 hari. Kondisi pertumbuhan pada masingmasing stadia dapat dijelaskan sebagai berikut.

$\underline{\text { Stadia vegetatif }}$

1. Tahap Perkecambahan benih (germination)

Pada fase ini benih akan menyerap air dari lingkungan (karena perbedaan kadar air antara benih dan lingkungan), masa dormansi akan pecah ditandai dengan kemunculan radicula dan plumule. Faktor yang mempengaruhi perkecambahan benih adalah kelembaban, cahaya dan suhu. Tahap perkecambahan benih berakhir sampai daun pertama muncul, memerlukan waktu 3-5 hari.

2. Tahap Pertunasan (seedling stage)

Tahap pertunasan mulai begitu benih berkecambah hingga menjelang anakan pertama muncul. Pada awal di persemaian, mulai muncul akar seminal hingga kemunculan akar sekunder (adventitious) membentuk sistem perakaran serabut permanen dengan cepat menggantikan radikula dan akar seminal sementara. Di sisi lain tunas terus tumbuh, dua daun lagi terbentuk. Daun terus berkembang dengan kecepatan 1 daun setiap 3-4 hari selama tahap awal pertumbuhan sampai terbentuknya 5 daun sempurna yang menandai akhir fase ini.

Dengan demikian pada umur 15 -20 hari setelah sebar, bibit telah mempunyai 5 daun dan sistem perakaran yang berkembang dengan cepat. Pada kondisi ini, bibit siap dipindahtanamkan.

3. Tahap Pembentukan anakan (tillering stage)

Setelah kemunculan daun kelima, tanaman mulai membentuk anakan bersamaan dengan berkembangnya tunas baru. Anakan muncul dari tunas aksial (axillary) pada buku batang dan menggantikan tempat daun serta tumbuh dan berkembang. Bibit ini menunjukkan posisi dari dua anakan pertama yang mengapit batang utama dan daunnya. Setelah tumbuh (emerging), anakan pertama memunculkan anakan sekunder, demikian seterusnya hingga anakan maksimal.

Pada fase ini, ada dua tahapan penting yaitu pembentukan anakan aktif kemudian disusul dengan perpanjangan batang (stem elongation). Kedua tahapan ini bisa tumpang tindih, tanaman yang sudah tidak membentuk anakan akan mengalami perpanjangan batang, buku kelima dari batang di bawah kedudukan malai memanjang hanya 2-4 $\mathrm{cm}$ sebelum pembentukan malai. Sementara tanaman muda (tepi) terkadang 
masih membentuk anakan baru sehingga terlihat perkembangan kanopi sangat cepat. Secara umum, fase pembentukan anakan berlangsung selama kurang lebih 30 hari. Pada tanaman yang menggunakan sistem tabela (tanam benih langsung) periode fase ini mungkin tidak sampai 30 hari karena bibit tidak mengalami stagnasi seperti halnya tanaman sistem tapin yang beradaptasi dulu dengan lingkungan barunya sesaat setelah pindah tanam (transplanting).

\section{Stadia Reproduktif}

1. Tahap Inisiasi Bunga / Primordia (Panicle Initiation)

Perkembangan tanaman pada tahapan ini diawali dengan inisiasi bunga. Bakal malai terlihat berupa kerucut berbulu putih (white feathery cone) panjang 1-1,5 mm. Pertama kali muncul pada ruas buku utama (main culm) kemudian pada anakan dengan pola tidak teratur. Ini akan berkembang hingga bentuk malai terlihat jelas sehingga bulir (spikelets) terlihat dan dapat dibedakan.

Malai muda meningkat dalam ukuran dan berkembang ke atas di dalam pelepah daun bendera menyebabkan pelepah daun menggembung (bulge).

2. Tahap Bunting (booting stage) Bunting atau booting merupakan penggembungan daun bendera. Bunting terlihat pertama kali pada ruas batang utama. Pada tahap ini, ujung daun layu (menjadi tua dan mati) dan anakan non-produktif terlihat pada bagian dasar tanaman.

3. Tahap Keluar Malai (heading stage)
Tahap selanjutnya dari fase ini adalah tahap keluar malai. Heading ditandai dengan kemunculan ujung malai dari pelepah daun bendera. Malai terus berkembang sampai keluar seutuhnya dari pelepah daun. Akhir fase ini adalah tahap pembungaan yang dimulai ketika serbuk sari menonjol keluar dari bulir dan terjadi proses pembuahan.

4. Tahap Pembungaan (flowering stage)

Pada pembungaan, kelopak bunga terbuka, antera menyembul keluar dari kelopak bunga (flower glumes) karena pemanjangan stamen dan serbuksari tumpah (shed). Kelopak bunga kemudian menutup. Serbuk sari atau tepung sari (pollen) jatuh ke putik, sehingga terjadi pembuahan. Struktur pistil berbulu dimana tube tepung sari dari serbuk sari yang muncul (bulat, struktur gelap dalam ilustrasi ini) akan mengembang ke ovary.

Proses pembungaan berlanjut sampai hampir semua spikelet pada malai mekar. Pembungaan terjadi sehari setelah heading. Pada umumnya, floret (kelopak bunga) membuka pada pagi hari. Semua spikelet pada malai membuka dalam 7 hari. Pada pembungaan, 3-5 daun masih aktif.

Anakan pada tanaman padi ini telah dipisahkan pada saat dimulainya pembungaan dan dikelompokkan ke dalam anakan produktif dan nonproduktif.

Stadia Pemasakan / Pematangan

1. Tahap matang susu ( Milk Grain Stage ) 
Tiga tahap akhir pertumbuhan tanaman padi merupakan fase pemasakan. Pada tahap ini, gabah mulai terisi dengan bahan serupa susu. Gabah mulai terisi dengan larutan putih susu, dapat dikeluarkan dengan menekan/menjepit gabah di antara dua jari. Malai hijau dan mulai merunduk. Pelayuan (senescense) pada dasar anakan berlanjut. Daun bendera dan dua daun di bawahnya tetap hijau. Tahap ini paling disukai oleh walang sangit. Pada saat pengisian, ketersediaan air juga sangat diperlukan. Seperti halnya pada fase sebelumnya, pada fase ini diharapkan kondisi pertanaman tergenang $5-7 \mathrm{~cm}$.

2. Tahap gabah $1 / 2$ matang (dough grain stage)

Pada tahap ini, isi gabah yang menyerupai susu berubah menjadi gumpalan lunak dan akhirnya mengeras. Gabah pada malai mulai menguning. Pelayuan (senescense) dari anakan dan daun di bagian dasar tanaman nampak semakin jelas. Pertanaman terlihat menguning. Seiring menguningnya malai, ujung dua daun terakhir pada setiap anakan mulai mengering.

3. Tahap gabah matang penuh (mature grain stage)

Setiap gabah matang, berkembang penuh, keras dan berwarna kuning. Tanaman padi pada tahap matang $90-100 \%$ dari gabah isi berubah menjadi kuning dan keras. Daun bagian atas mengering dengan cepat (daun dari sebagian varietas ada yang tetap hijau). Sejumlah daun yang mati terakumulasi pada bagian dasar tanaman. Berbeda dengan tahap awal pemasakan, pada tahap ini air tidak diperlukan lagi, tanah dibiarkan pada kondisi kering.

Kebutuhan air tanaman padi berbeda-beda menurut fase fenologinya. Tanaman padi membutuhkan air paling banyak pada fase vegetative, mencapai 320 $\mathrm{mm}$. Hal ini berkaitan dengan lamanya fase vegetatif yang mencapai 60 hari pada tanaman padi genjah. Kebutuha air pada fase pembentukan anakan sekitar $50 \mathrm{~mm}$, fase pembungaan sekitar $80 \mathrm{~mm}$, pengisian gabah sekitar $85 \mathrm{~mm}$ dan fase pematangan sekitar $65 \mathrm{~mm}$.

Berdasarkan tingkat urgensinya, masing-masing stadia pertumbuhan tanaman padi membutuhkan air yang berbeda-beda pula. Pada stadia pembentukan anakan aktif dan fase bunting merupakan fase-fase kritis tanaman padi terhadap ketersediaan air. Kekurangan atau kelebihan air pada fase ini dapat mengganggu pertumbuhan tanaman (Vergara, 1976), sebagaimana dapat disimak pada gambar berikut. 


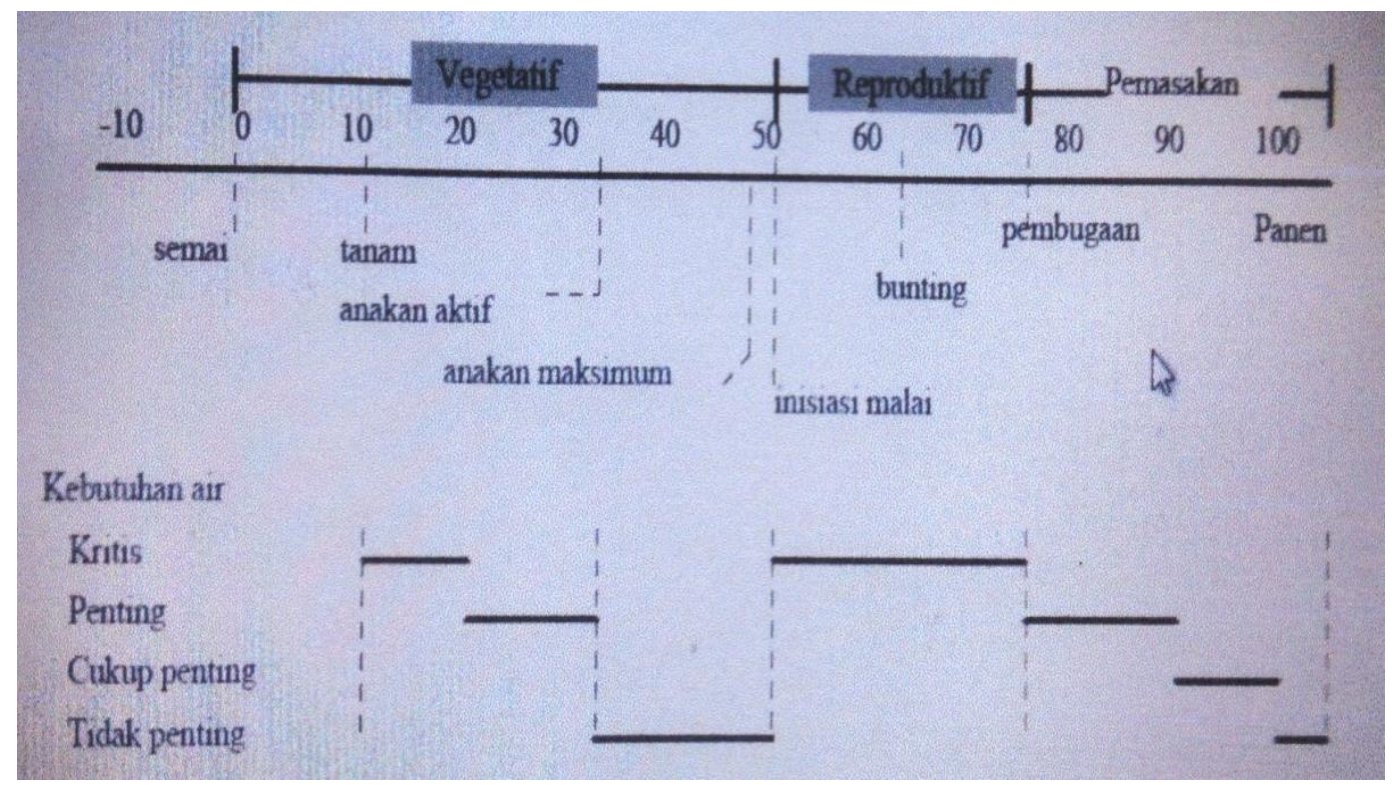

Gambar 2. Kebutuhan air pada setiap fase pertumbuhan tanaman padi

\section{Dampak Peningkatan Kelebihan Air terhadap Pertumbuhan dan Hasil Padi Sawah}

Salah satu dampak La Nina adalah terjadinya curah hujan yang tinggi dalam waktu singkat yang kadang-kadang diikuti dengan angin kencang atau badai. Keadaan ini dapat menyebabkan terjadinya peningkatan permukaan air hingga melampaui batas toleransi tanaman. Penelitian untuk mengkaji pengaruh kelebihan air (penggenangan, banjir, dll.) pada tanaman padi telah cukup intensif dilakukan. Secara umum dinyatakan bahwa air yang berlebih dapat mengganggu pertumbuhan dan hasil tanaman padi. Faktor penyebab utama kerusakan tanaman padi akibat genangan adalah terbatasnya pertukaran udara, baik berupa karbondioksida $\left(\mathrm{CO}_{2}\right)$ maupun oksigen $\left(\mathrm{O}_{2}\right)$ yang menghambat proses fotosintesis dan respirasi tanaman (Setter et al., 1997 dalam Hairmansis et al., 2012). Menurut Jackson dan Ram, 2003) beberapa kondisi yang mempengaruhi antara lain :
1. Laju pertukaran gas yang rendah Hal ini terjadi karena adanya koefisien difusi gas yang rendah ke dalam air $\left(0,21 \mathrm{~cm}^{2} \cdot \operatorname{det}^{-1} \mathrm{di}\right.$ udara menjadi $2,38.10^{-5} \mathrm{~cm}^{2}$.det- ${ }^{1}$ di dalam air). Dalam kondisi air yang tidak bergerak, kondisi diseliling jaringan tanaman juga menjadi kurang baik.

2. Pengaruh naungan

Penurunan intensitas cahaya yang diterima daun akibat terjadinya proses penaungan. Sinar matahari menjadi tidak sepenuhnya dapat menyentuh tanaman, akibat terhalang oleh adanya genangan air yang dapat terjadi pada air yang jernih apalagi pada air yang keruh.

3. Kerusakan mekanis

Daun akan mengalami kerusakan fisik akibat laju aliran air yang deras atau akibat benturan pratikel yang bergerak di dalam air.

4. Kapasitas bahan terlarut

Dalam kondisi tergenang, air akan melarutkan banyak bahan partikel yang bisa bermanfaat tetapi juga dapat berbahaya bagi 
tanaman. $\mathrm{CO} 2$ terlarut yang rendah berpengaruh terhadap pertumbuhan tanaman, khususnya akibat rendahnya produksi karbohidrat.

Terdapat 2 (dua) tipe rendaman penuh yang dapat terjadi pada pertanaman padi sawah, yaitu rendaman air dalam jangka panjang (stagnant flood) yang umum terjadi pada lahan rawa lebak, dan rendalam air jangka pendek (flash flood) yang terjadi selama 1-2 minggu yang terjadi pada lahan rawa lebak dangkal dan di lahan sawah dengan tata air buruk ketika curah hujan tinggi (Hairmansis, et al., 2012). Tingkat gangguan pertumbuhan dan hasil tanaman padi sawah tergantung pada tingkat genangan dan ketahanan tanaman padi bersangkutan terhadap kelebihan air. Mahmod et al. (2014) melaporkan, genangan antara mengakibatkan suasana lahan menjadi anaerob (kekurangan oksigen) dan penampilan morfologi, fisiologi dan komponen hasil sebagai respon tanaman terhadap kondisi tingkat aerobik berbeda-beda menurut varietas dan perlakuan lainnya.

Ketika terjadi penggenagan air pada lahan, air akan memenuhi pori-pori tanah, udara didesak keluar, difusi gas berkurang dan senyawa beracun terakumulasi akibat kondisi anaerobik. Semua perubahan ini sangat mempengaruhi kemampuan tanaman padi sawah untuk bertahan hidup.

Selain berpengaruh terhadap pertumbuhan dan hasil tanaman padi, kondisi anaerob akibat kelebihan air juga dapat mempengaruhi perkecambahan benih padi, seperti yang dilaporkan oleh Mapelli et al. (1995). Lebih lanjut menurut Mapelli et al. (1995), toleransi benih padi terhadap kekurangan oksigen (anoxia) ada kaitannya dengan level ABA endogenous.

Meskipun secara umum tanaman padi sawah memiliki kemampuan beradaptasi terhadap kelebihan air, tetapi kelebihan air yang terjadi hingga merendam seluruh kanopi tanaman atau terjadi pada fase-fase pertumbuhan tertentu dapat menimbulkan kerusakan fisiologis yang nyata, yang berdampak lebih lanjut terhadap hasil (Ito et al., 1999).

Pengaruh kelebihan air pada pertumbuhan dan hasil tanaman padi dapat terjadi secara langsung pada tanaman ataupu secara tidak langsung melalui perubahan beberapa sifat kimia tanah. Menurut Unger et al., 2009 dalam Mungai et al., 2011), beberapa perubahan sifat kimia tanah yang umum terjadi antara lain $\mathrm{pH}$ tanah, daya hantar listrik, potensial redoks tanah (Eh), aktivitas denitrifikasi dan produksi bahan organik. Dampak lanjutan dari perubahan sifat kimia tanah ini antara lain berupa perubahan ketersediaan nutrisi, aktvitas enzim dan dinamika bahan organik.

Potensial redoks tanah (Eh) sering dianggap sebagai indikator yang paling tepat dari perubahan kimia yang terjadi saat banjir. Eh umumnya menurun selama tergenang air tanah. Potensial redoks tidak hanya merupakan indikator dari kadar O2 (Eh sekitar +350 mV dalam kondisi anaerob) karena kondisi reduktif menyebabkan kompetisi tinggi akan $\mathrm{O} 2$, tetapi juga mempengaruhi ketersediaan dan konsentrasi pelbagai nutrisi tanaman

Akan tetapi, perubahan Eh dipengaruhi oleh bahan organik serta Fe dan Mn. Reduksi tanah memacu pelepasan kation dan fosfor melalui 
adsorpsi ion besi dan pelarutan oksida. Kondisi tanah yang reduktif juga mendukung produksi etanol, asam laktat, asetaldehida, dan asam asetat dan formiat.

Karakteristik kimia tanah lainnya yang sangat dipengaruhi oleh kondisi genangan adalah $\mathrm{pH}$ tanah, yang berkorelasi negatif dengan Eh (Singh 2001; Zarate-Valde et al., 2006). pH tanah umumnya cenderung meningkat menuju netral pada kondisi tergenang air (Lu et al., 2004). Peningkatan pH dapat dijelaskan oleh pelarutan karbonat dan bikarbonat di awal genangan (Lu et al., 2004). pH tanah juga mempengaruhi perombakan bahan organik tanah dan proses seperti mineralisasi, nitrifikasi, dan hidrolisis urea (Probert dan Keating, 2000).

Salah satu efek utama genangan air adalah rendahnya keberadaan $\mathrm{O}_{2}$ di bagian tanaman yang terendam, karena gas $\mathrm{O}_{2}$ berdifusi 10.000 lebih cepat di udara dibandingkan di dalam air. Pengaruh terbatasnya $\mathrm{O}_{2}$ pada metabolisme sel tergantung pada konsentrasinya dan penurunan ketersediaan $\mathrm{O}_{2}$ secara gradual pada akar memiliki berbagai pengaruh pada metabolisme tanaman: i) normoxia memungkinkan respirasi aerobik dan metabolisme normal dan sebagian besar ATP dihasilkan melalui fosforilasi oksidatif, ii) hipoksia terjadi ketika penurunan $\mathrm{O}_{2}$ yang tersedia mulai menjadi faktor pembatas untuk produksi ATP melalui fosforilasi oksidatif dan, iii) anoxia ketika ATP hanya dihasilkan melalui glikolisis fermentasi, karena tidak ada $\mathrm{O}_{2}$ yang tersedia lagi. Dengan demikian, karena kondisi anaerobik berkembang di tanah tergenang air, maka ada peningkatan jumlah produk sampingan dari metabolisme fermentasi yang terakumulasi di lingkungan perakaran dan kadar $\mathrm{CO}_{2}$, metana, dan asam lemak volatile meningkat (Pezeshki, 2001). Penurunan energi yang tersedia memiliki konsekuensi yang dramatis pada proses seluler, yang menyebabkan ketidakseimbangan dan/atau kekurangan air dan hara nutrisi (Dat et al., 2006). Selain itu, perubahan lingkungan ini juga dapat membuat tanaman lebih rentan terhadap stres lainnya, khusus terhadap infeksi patogen.

\section{Respon Metabolisme Tanaman Terhadap Peningkatan Kelebihan Air}

Akibat langsung dari peningkatan kelebihan air (genangan air) adalah periode hipoksia, diikuti oleh penurunan tajam dari $\mathrm{O}_{2}$ yang menyebabkan kondisi anoksia. Kekurangan oksigen seluler disebut hipoksia ketika kadar oksigen membatasi respirasi mitokondria dan anoksia saat respirasi benar-benar terhambat. Ketika respirasi menurun, aliran elektron melalui jalur respirasi berkurang, sehingga mengurangi produksi ATP. Akibatnya, bahan kimia pengoksidasi yaitu nicotinamide adenin dinukleotida (NAD) harus dihasilkan melalui jalur alternatif yang tidak menggunakan $\mathrm{O}_{2}$ sebagai akseptor elektron terminal. Ketika fosforilasi oksidatif adenosine difosfat (ADP) terbatas, maka tanaman mengubah metabolismenya dari respirasi aerobik menjadi fermentasi anaerob, seperti dapat disimak pada Gambar 2. Jalur fermentasi anaerob berfungsi sebagai rute metabolisme aman dan mencakup dua tahap: karboksilasi piruvat menjadi asetaldehida 
(dikatalisis oleh piruvat dekarboksilase, PDC) dan berikutnya reduksi asetaldehida menjadi etanol dengan diiringi oksidasi NAD (P) $\mathrm{H}$ menjadi NAD $(\mathrm{P})$, dikatalisis oleh alkohol dehidrogenase (ADH). Jalur metabolisme fermentasi hanya memungkinkan sintesis 2 mol ATP dibandingkan 36 ATP per mol glukosa yang dihasilkan pada respirasi aerobik.Untuk mengimbangi defisit energi, glikolisis dipercepat, menyebabkan menipisnya cadangan karbohidrat (Pasteur efek). Tidak mengherankan, enzim yang berperan dalam jalur fermentasi (lihat PDC dan ADH di atas) termasuk kelompok dari sekitar 20 ANPS, diinduksi secara selektif selama stres hipoksia, sedangkan keseluruhan sintesis protein berkurang (Chang et al., 2000). ANPS yang diinduksi dalam kondisi hipoksia adalah enzim glikolisis, fermentasi etanol, proses yang terkait dengan metabolisme karbohidrat, tetapi juga yang lainnya yang terlibat dalam pembentukan aerenchyma (xyloglucans endotransglycosylase) dan pengendali $\mathrm{pH}$ sitoplasma.

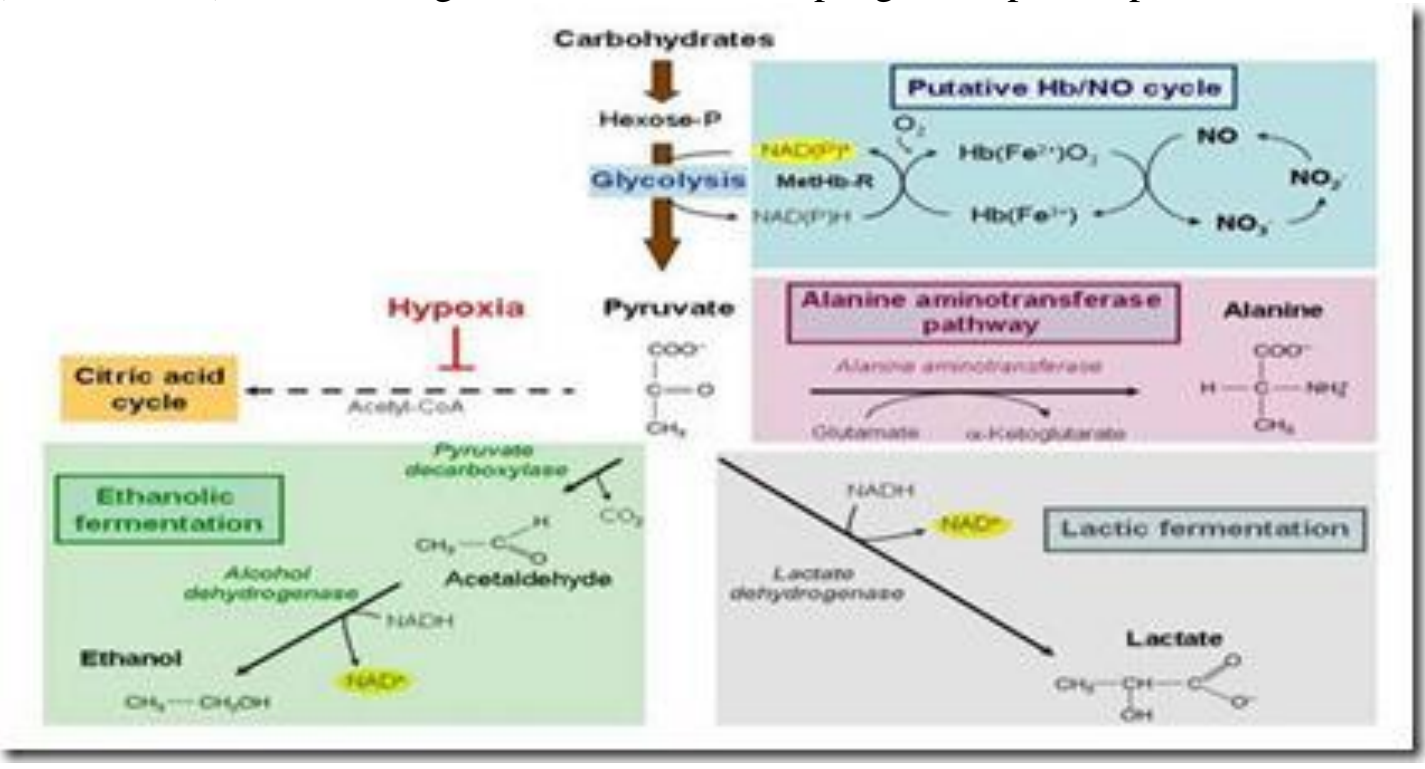

Gambar 3. Skema diagram jalur metabolik utama yang dusulkan pada saat tanaman mengalami cekaman kelebihan air

\section{Adaptasi Tanaman Padi Sawah terhadap Kelebihan Air}

Adaptasi yang dimaksud dalam hal ini adalah proses penyesuaian kondisi internal tanaman agar dapat tumbuh dan berkembang normal dalam kondisi tercekam kelebihan air (genangan air). Kemampuan adaptasi ini tergantung pada tipikal genetik varietas yang ditanam. Beberapa studi yang pernah dilakukan oleh beberapa peneliti menunjukkan tingkat toleransi tanaman padi terhadap kelebihan air sangat beragam menurut genotipa yang ditanam. Tanaman padi dikatakan toleran terhadap genangan sementara (flash flood) jika tanaman padi dapat bertahan hidup dalam waktu 10-14 hari dalam kondisi terendam penuh dan dapat memperbaharui pertumbuhannya setelah ketinggian air normal (Hattori et al., 2011).

$\begin{array}{ccc}\text { Secara } & \text { umum adaptasi } \\ \text { tanaman padi sawah terhadap }\end{array}$


cekaman kelebihan air dapat dikaji dari aspek fosiologis, biokimia maupun molekuler.

a. Kemampuan Adaptasi pada Aspek Fisiologi dan Biokimia Menurut Ta Liao dan Ho Lin (2001), secara fisiologis perbedaan kemampuan adaptasi tanaman padi sawah terhadap kelebihan air tergantung pada : (1) kapasitas respirasi akar, (2) metabolisme anaerobik akar, (3) regulasi hormonal, (4) kesetimbangan metabolism antara pucuk dan akar, (5) pertukaran gas pada daun, dan (6) kapasitas fotosintesis pada sel mesofil.

Mahmod et al. (2014) menambahkan, respon fisiologis tersebut dapat dikur melalui parameter pertumbuhan dan hasil, seperti indek luas daun, total klorofil, laju fotosintesis, laju transpirasi, dan komponen hasil seperti hasil gabah, biomasa dan indeks panen.

Vigor benih berkorelasi positif dengan vigor tanaman. Untuk itu beberapa peneliti melakukan uji ketahanan tanaman padi sawah pada fase kecambah, seperti yang dilakukan oleh Mapelli et al. (1995). Perkecambahan dan pertumbuhan tanaman padi secara prinsip dipengaruhi oleh kadar ABA dan IAA endogenous. Kadar ABA lebih berpengaruh dibanding kadar IAA.

Pada tanaman jagung ditemukan ada 20 polipetida anaerobik (anaerob polypeptides/ANPs) pada akar jagung. Namun untuk tanaman padi belum tergali informasinya. Makin banyak ditemukan ANPs, menunjukkan respon tanaman terhadap kondisi kelebihan air yang menyebabkan kondisi tanah anaerobic bersifat sangat kompleks (Suwignyo, 2007). Secara keseluruhan, ada tiga tahapan proses respon tanaman terhadap kondisi kelebihan air yang menyebabkan deficit oksigen, yaitu :

1) Tahap pertama (0-4 jam)

Terjadi proses induksi yang cepat atau aktivasi signal komponen transduksi.

2) Tahap kedua (4-24 jam)

Merupakan proses adaptasi metabolik. Pada tahap ini berlangsung induksi glokolisis dan gen fermentasi yang penting untuk menjaga keberlangsungan produksi energy. Respon metabolic pada tahap ini lebih kompleks dari yang diduga karena melibatkan perubahan dalam metabolism nitrogen. Pada tahap ini juga dihasilkan enzim yang berperan dalam biosintesis etilen, yaitu aminocyclopropane

carboxylic acid synthase (ACC synthase).

3) Tahap ketiga (24-48 jam)

Tahap ini sangat penting bagi keberlangsungan hidup tanaman akibat adanya oksigen yang rendah, yaitu pembentukan aerenchyma di perakaran. Suatu enzim yang berperan dalam pengendoran (lossening) dinding sel yaitu xyloglucan

endotransglycosylase juga terbetuk, sehingga dinding sel menjadi lebih eleastis. Pembentukan aerenchyme bukan merupakan pengaruh langsung dari kekurangan oksigen, tetapi dipacu oleh tahap 1 dan 2 di atas, serta 
adanya akumulasi hormone etilen.

Tingkat toleransi tanaman padi sawah terhadap kelebihan air (kekurangan oksigen) pada dasatnya berkaitan dengan kemampuan tanaman untuk mengatasi kelangsungan tiga tahapan tersebut di atas. Tanaman yang biasa hidup di air pada umumnya mempunyai kemampuan untuk membentuk jaringan aerenchyma, sehingga oksigen di perakaran dapat disuplai dari bagian atas tanaman. Namun demikian, jika seluruh bagian tanaman terendam air, maka tidak ada lagi bagian tanaman yang mensuplai oksigen. Dalam kondisi seperti ini ketahanan tanaman sangat tergantung pada kemampuan untuk tetap melangsungkan metabolism tanaman dengan kondisi oksigen sangat rendah.

Selain melalui mekanisme tersebut di atas, Dannis et al. (2000) menyebutkan adanya peran enzim alcohol dehydrogenase $(\mathrm{ADH})$ dalam adaptasi benih padi untuk berkecambah dalam kondisi tergenang. Pada tanaman yang toleran ternyata mengandung enzim ADH lebih tinggi dibanding yang kurang toleran.

b. Kemampuan Adaftasi Tanaman Padi pada Aspek Molekuler

Studi genetika toleransi tanaman padi terhadap genangan, khususnya genangan sementara sudah dilakukan sejak tahun 1980an. Karakter toleran ini dikendalikan oleh beberapa gen yang bersifat dominan sebagian atau dominan penuh. Hasil identifikasi terhadap lokus Submergence1 (Sub1) pada kromosom 9 diketahui adanya gengen pengendali toleransi tanaman padi terhadap genangan. Gen ini pengkode pembentukan ethylene response factor (ERF). Varietas yang membawa gen Sub1 mampu bertahan hidup pada kondisi tergenang penuh sampai 2 minggu. Gen tersebut terkait dengan penurunan hormone etilen dan asam giberelat yang mencegah tanaman padi untuk tumbuh dan memanjang selama terendam (Xu et al., 2006). Dengan adanya gen Sub1, pembentukan protein SLR1 dan SLRL1 berlangsung stabil dan memacu kerja enzim Phyruvate Decarboxylase (PDC) dan alcohol dehydrogenase (ADH) sehingga terjadi pemanjangan pucuk dan konsumsi karbohidrat dalam kondisi kekurangan oksigen. Peran gen Sub1 dalam toleransi tanaman padi terhadap genangan dapat disimak pada gambar berikut. 


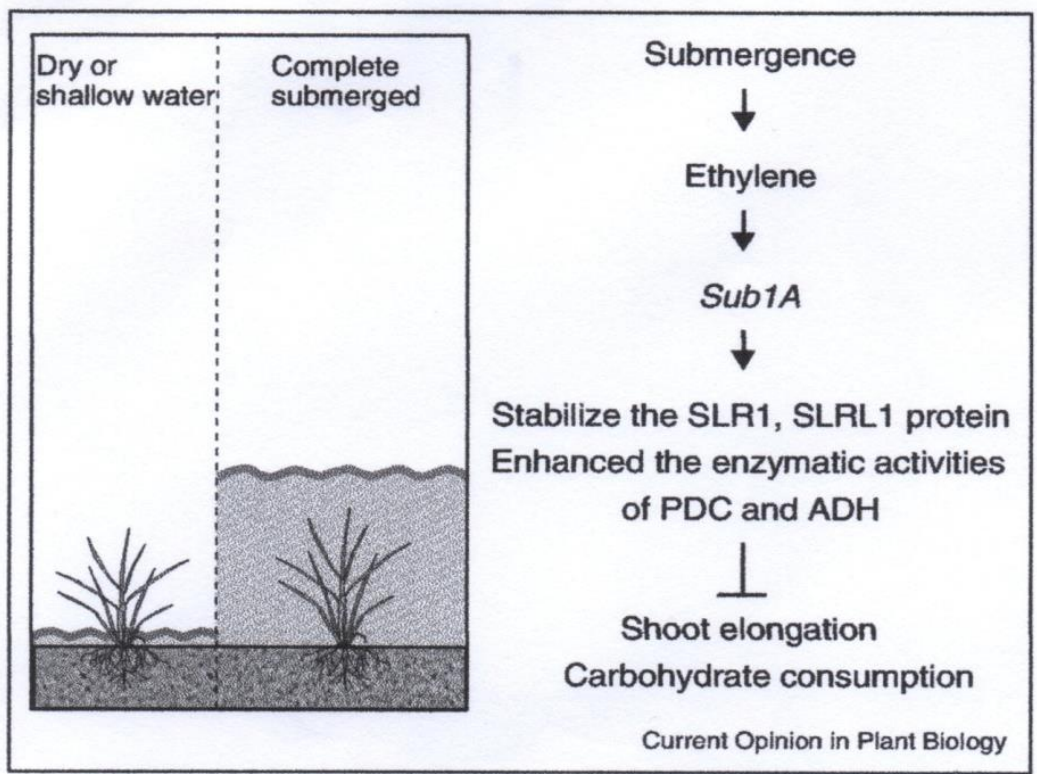

Gambar 4. Mekanisme molekuler toleransi tanaman padi terhadap kelebihan air

Namun masih disayangkan, gen toleran tersebut berasal dari varietas lokal FR13A yang memiliki daya gabung sifat agronomi tergolong rendah (Mackill et al., 1996). Galur-galur yang mengandung gen Sub1 dari IRRI telah diintroduksi ke Indonesia. Hasil uji multilokasi yang telah dilakukan menunjukkan ada dua galur padi toleran terhadap genengan, yaitu IR05F101 (Swarna-Sub1) dan IR07F102 (IR64-Sub1) (Hairmansis et al., 2012).

\section{SIMPULAN}

Berdasarkan uraian pada Bab-bab di atas dapat dirumuskan beberapa simpulan sebagai berikut.

1. Tingkat gangguan pertumbuhan dan hasil tanaman padi akibat kelebihan air tergantung pada tingkat toleransi varietas, tingkat genangan dan lama waktu terjadinya genangan.

2. Padi memiliki kemampuan morfologis bertahan dalam kondisi tergenang karena memiliki jaringan aerenchyma.
Namun peran arenchyma ini sangat ditentukan oleh ada tidaknya jaringan pemasok oksigen pada tanaman.

3. Secara fisiologis adaptasi tanaman padi sawah terhadap kelebihan air tergolong kompleks. Tanaman yang menghasilkan PDC dan ADH lebih banyak lebih toleran terhadap genangan.

4. Secara molekuler, tanaman yang mengandung gen Sub1 lebih tahan terhadap kelebihan air.

\section{DAFTAR PUSTAKA}

Bouman, B.A.M. 2009. How Mauch Water Does Rice Use. Rice Today $6: 38$.

Dai, Q., Y. Tian dan X. Lu. 2012. Flooding Response in Rice : Ethylene Networks and Sugar Signaling. African J. of Biotech. 11 (12) : 2822-2826.

Hairmansis, A., Supartono, B. Kustianto, Suwarno dan H. pane. Perakitan dan Pengembangan varietas Unggul baru Pado 
Toleran Rendaman Air Impara 4 dan Inpara 5 untuk Daerah Rawan banjir. J. Litbang Pert. 31 (1) : 1-7.

Hattori, Y., K. Nagai dan M. Ashikari. 2011. Race Growth Adapting to Deepwater. Current Opinion in Palnt Bilogy 14 : 100-105.

Ito, O., E. Ella dan N. Kawano. 1999. Physiological Basis of Submergence Tolerance in Rainfed Lowland Rice Ecosistem. Field Crops Res. 64 : 75-90.

Jackson, M.B. dan P.C. Ram. 2003. Physiological and Molecular Basis of Susceptibility and Tolerance of Rice Plants to Complete Submergence. J. Ann Bot. 91 (20) : 227-241.

Mahmod, I.F., S.S. Barakbah, N. Osman dan O. Omar. 2014. Physioloical Response of Local Rice Varieties to Aerobic Condition. Int. J. of Agric \& Biol. $16: 738-744$.

Mapelli, S., F. Lacatelli dan A. Bertani. 1995. Effect of Anaerobic Environment on Germination and Growth of Rice and Wheat : Wndogenous Levels of ABA and IAA. Bulg. J. Palnt Physiol. 21 (2-3) : 3141.

Ta Liao, C. dan C. HolIn. 2001. Physiological Adaptation of Crop Plants to Flooding Stress. Proc. Natl. Sci. Counc 25 (3) : 148-157.

Suciantini. 2015. Interaksi Iklim (Curah Hujan) Terhadap Produksi Tanaman Pangan di Kabupaten Pacitan. Proseding Seminar Nasional Masyarakat Biodiversiti Indonesia 1 (2) : 358-365.
Suwognyo, R.A. 2007. Ketahanan tanaman Padi Terhadap Kondisi Terendam : pemahaman Terhadap Karakter Fisiologis untuk mendapatkan Kultivar Padi yang Toleran di Lahan Rawa Lebak. Makalah pada Kongres Ilmu Pengetahuan Wilayah Indonesia Bagian Barat, Palembang, 3-5 Juni 2007.

Vergera, S.B. 1976. Physiological and Morphological Adaptability of Rice Varieties to Climate. In Climate and Rice, IRRI Philippines. 